\title{
The impacts of International Financial Crisis on Saudi Arabia Economy: Evidence from Asymmetric SVAR modelling
}

\author{
Hassan B. Ghassan ${ }^{1,2,}$, Hassan R. Alhajhoj ${ }^{3}$ and Mohammed Kbiri Alaoui ${ }^{4}$ \\ ${ }^{1}$ Department of Economics, Umm Al-Qura University, P.O. Box 715 Makkah 21955, Saudi Arabia \\ ${ }^{2}$ Department of Economics, Business School, King Faisal University, P.O. Box 400 Al-Hassa 31982, Saudi \\ Arabia \\ ${ }^{3}$ Department of Economics, Business School, King Faisal University, P.O. Box 400 Al-Hassa 31982, Saudi \\ Arabia \\ ${ }^{4}$ Department of Mathematics, College of Sciences, King Khalid University, P.O Box 9004, Abha, Saudi Arabia
}

\begin{abstract}
This paper aims to measure the impacts of International Financial Crisis on the performance of the Saudi Arabian economy from 1968 to 2010. Linear and non-linear SVAR methodologies are used to exhibit the interdependence between the process of international liquidity, net-exports and economic growth. The empirical models show that the impacts of international financial crisis lead to an immediate drop in the net-exports and conduct to reduce gradually real economic growth during roughly three years. In the horizon, the variation in economic growth is largely attributed to domestic supply shocks, but negative shocks of international financial markets drove to reduce the economic growth in the long-run by $1.04 \%$.
\end{abstract}

Keywords: Financial Crisis, International Liquidity, Asymmetric SVAR Model, Saudi Arabia.

\section{INTRODUCTION}

The last international financial crisis related to bank crises and macroeconomic mismanagement has significant impacts on financial and economic activities. The bank crises result from their domestic and international involvements in high risk investment and speculation. The interconnectivity of the international financial system has been largely ignored by academic economics (Colander et al. 2009).

The performance of public and private institutions is affected by abroad exogenous shocks through the real and financial international markets. But, the huge accumulated reserves of foreign currencies since 2006 contribute to reduce the negative impacts caused by the international financial crisis and the oil decreasing demand of industrialized economies. Generally, due to their experience from the oil market volatility, the GCC (Gulf Cooperation Council) governments have the ability to deal with financial and economic crises.

Remarkably, the bankruptcies of financial institutions during 2008-2009 financial crisis in the United States (about 140 in the USA only according to

*Address correspondence to this author at the Department of Economics, College of Economics and Islamic Finance, Umm Al-Qura University, P. O. Box 715 Makkah 21955, Saudi Arabia; Tel: +966-025270000; Fax: +966025564560, +966-025593997; E-mail: hbghassan@yahoo.com, hbghassan@uqu.edu.sa

JEL Classification: C51 E22 E44 G15 the Federal Deposit Insurance Corporation ${ }^{1}$ ) and Europe decline the banking system activities, leading to decrease the economic growth rates and increase the unemployment rates (Portes 2009; Dell' Ariccia, Detragiache and Rajan 2008). By considering US economy and a panel of Latino-American economies without OPEC countries members, Mackowiak (2007) indicates that the external shocks i.e. sudden changes in the U.S. monetary policy influence the exchange rate variations of the emerging economies and their real output. Focusing on interest rate and exchange rate with monthly data and using symmetric SVAR framework, he surprisingly suggests that the real output of emerging economies tracks US real output. But, he indicates that the sign of the response of GDP to U.S. contractionary monetary policy shock is ambiguous. In our purpose, we suggest that the effects -mainly on the net exports and GDP- of international financial crisis as the U.S. financial crisis would not be confusing, because they depend on the underlying features of the economies.

The impacts of the last international financial crisis on real economy of Saudi Arabia, as an important country in terms of international liquidity and oil production, require empirical analyses. The SVAR model in linear and non-linear frameworks allows visualizing the impacts of financial markets shocks on

${ }^{1}$ Source: http://www.fdic.gov/bank/individual/failed/banklist.html

(C) 2013 Lifescience Global 
real economy through impulse response functions and forecast error variance decomposition.

The theoretical background is showed in the second section. The data and underlying variables are presented in third section. The SVAR methodology, analyzing the dynamic interactions between real and financial variables, is exhibited in section four. The fifth section points out the results of basic statistical tests, estimation and interprets the main findings. The sixth section concludes the paper.

\section{STYLIZED FACTS AND THEORETICAL BACK- GROUND}

\subsection{International Stylized Facts}

The international financial crises are related to the huge flows of foreign capital, which finance private projects like in Asia and buy government bonds and securities as in the United States (Reinhart and Rogoff 2008 ; Galindo, Schiantarelli and Weiss 2007). In 2006, China possesses globally $21.1 \%$ of US long run Treasury bonds and $53.9 \%$ of other US government bonds (Morrison and Labonte 2008). Since the beginning of third millennium, the banks depend increasingly on domestic and foreign financial sources. The financial liberalization between markets across the world contributes to increase the financial liquidity flows for extending the direct and financial investments (Bordo, Meissner and Stuckler 2010, Bracke and Fidora 2008, Calvo 1998). The international liquidity of some economies are largely allocated to finance infrastructure projects and invested in bonds and securities markets of occident governments e.g. USA. The concurrence between banks leads to reduce the interest rate and includes high-risky borrowers extending the mortgage system to the real estate sector (Michaud and Upper 2008).

In 2006, to limit the inflation wave, the US Federal Reserve adopts a restricted monetary policy by increasing the interest rate which conducts to reduce the economic growth (Bourland 2008). When banks cannot pay their debts to financial institutions, they convert the allowed loans to negotiable bonds traded on financial markets i.e. debt securities. Also, when the creditor banks fail to recover the borrower's debts, the bubble of financial system blows up and the bankruptcy of several institutions happened.

In 2005, the rates of saving surplus increased in some developed and developing countries; this excess of saving on investment is labeled "saving glut" (Bernanke 2005; IMF 2008). In contrast, the level of saving per capita has been reduced in the occidental economies, whereas the level of consumption per capita increased as consequence of financing availability and declining of loans interest rates (Clarida 2005). The financial crisis results from borrower defaults which causing severe weakness in liquidity of securities (Kashyap, Rajan and Stein 2008). An attraction of global savings is requested for a new liquidity to safe the financial system. The global codependency makes available the required liquidity from the foreign central banks, but less from the private investors. The intervention of central banks is necessary to prevent the collapse of the financial system by injecting necessary liquidity in banking institutions to ensure the banks work. It also sets a minimum guarantee of banks deposits to remove the depositors' panic and reduce their motivation to withdraw deposits from banks.

According to Roubini and Setser (2005), the huge current account deficit of USA may lead to a serious decline in dollar currency, conducting then shortly to the collapse of the financial system. The economies owning bonds and financial assets in US funds are constrained by the U.S. dollar volatilities and cannot avoid the loss in their financial assets. The countries, having huge reserves at their central banks, react differently to the dollar volatilities.

The China and Japan adopt flexible exchange rate to support their exports, other countries adopt the status-quo of their nominal exchange rate e.g. Saudi Arabia. The economies adopting a fixed exchange rate policy would be more vulnerable to abroad real and financial shocks (Edwards 2009). According to Sester and Ziemba (2007) estimation, the currencies in Saudi Arabia economy and SAMA (Saudi Monetary Authority) consist of $75 \%$ by US dollar and that the non reserve assets allocation is composed by $25 \%$ of shares, $10 \%$ of deposits and $65 \%$ as fixed revenues.

\subsection{Saudi Arabia Stylized Facts}

The revenues of oil export are the main financial sources in Saudi Arabia, which affect directly the balance of payments. Then, the perturbation in oil prices and export levels influences the current account and the official reserve assets (Mehrara and Oskoui 2007). During the last decade, the Saudi economy recorded continuous excess in payment balance and official reserves.

The negative impacts on international liquidity of Saudi Arabia are caused firstly by the erosion of the 
financial and real assets values mostly in United States, secondly by the decline in oil revenues due to lower demand of the industrialized economies. These impacts lead to a huge reduction in the international oil prices from 145 dollars per barrel to 40 dollars during the fourth quarter of 2008 and the first quarter of 2009. But, since beginning of the third millennium and before the crisis, the accumulation of the international liquidity, due to the exceptional increase in oil prices during the third quarter of 2008, contributes to absorb the negative impacts of the international financial crisis on Saudi economy.

The economic report of SAMA $\left(45^{\text {th }}, 2009\right)$ indicates the increase of foreign Saudi banks investments during 2009 which reached a high record. This raise results partially from the decline in the deposits returns due to the absence of government bonds emission during 2009 and the decrease in domestic reverse repo rate decided by SAMA, because the central bank considers that there is no domestic liquidity excess in the economy. ${ }^{2}$ But, this leads to increase the level of liquidity in banks, and then the banks invest their excess liquidity abroad, so the net foreign assets of banks recorded a significant increase between the fourth quarter of 2008 and 2009.

The growing of money supply at faster rate, compared to the GDP growth, signify that the Saudi Arabia economy suffer from the monetary risk inflation (Figure 1). In addition there is a "glut saving" phenomenon since exports exceed imports and international liquidity-GDP ratio is very high (Figures 2). This phenomenon encourages excessive risk taking by allowing large resources for foreign investments.

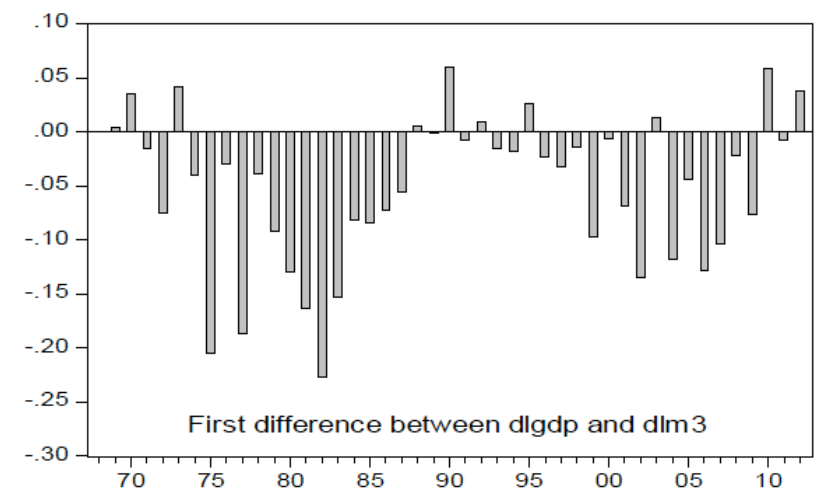

Figure 1: First difference between GDP growth and domestic liquidity growth of Saudi Arabia from 1968 to 2012.

${ }^{2}$ http://www.sama.gov.sa/sites/SAMAEN/ReportsStatistics/Pages/AnnualReport .aspx
Net-exports play an important role in the development process of Saudi Arabia economy (Figures 2). Obviously, the reliance on foreign demand made the Saudi economy more vulnerable to the international financial crisis (Woertz 2008).
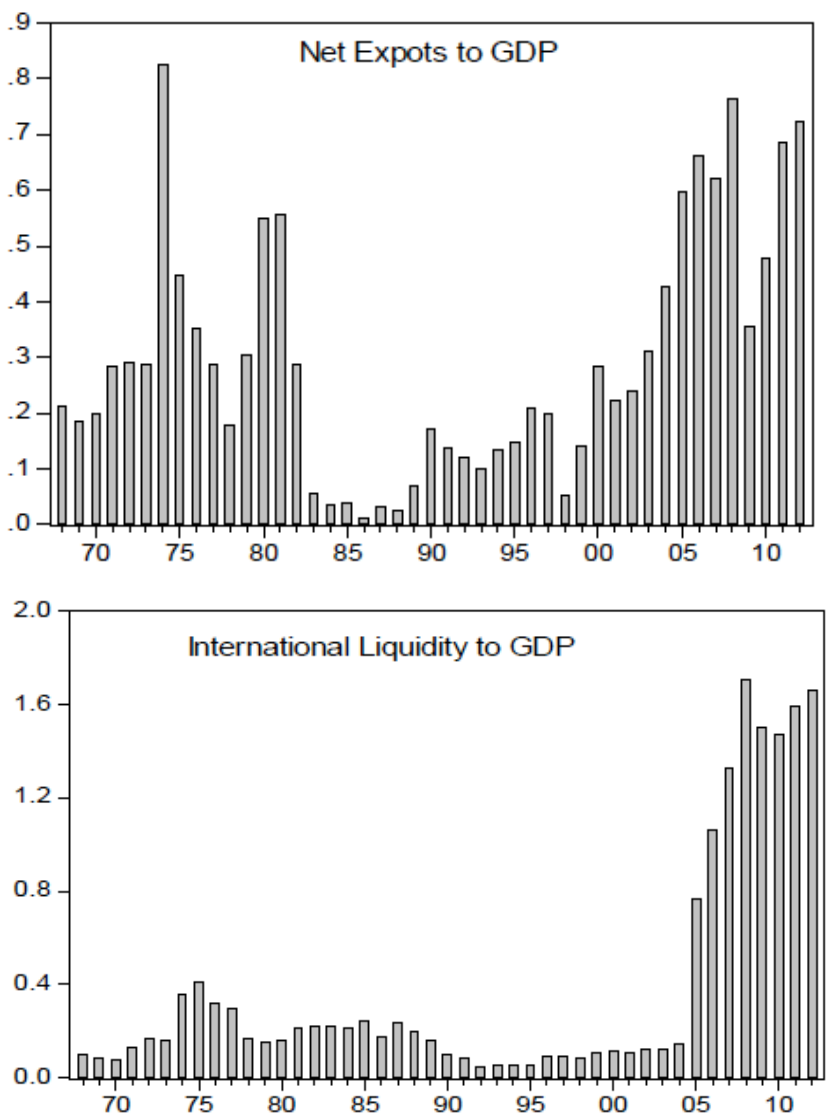

Figure 2: Net exports-GDP ratio and International LiquidityGDP ratio of Saudi Arabia from 1968 to 2012.

The focus on domestic demand poses significant challenges related to the new macroeconomic adjustments and the new look for economic cooperation in the GCC countries or most large framework. Even if the monetary policies of SAMA are mostly conservative, SAMA can use counter-cyclical macroeconomic policies to recover the financial system and boost the economic growth. The focus on domestic issues and regional cooperation or union as in Europe and East-Asia could mitigate the negative impacts of the global financial and economic crises.

\subsection{Theoretical Background}

Mishkin (1996) considers that the asymmetric information, between banks and investors linked by contracts, causes the financial crisis. He explains that the occurrence of financial crisis is mainly due to the moral hazard and adverse selection. During the 
international financial crisis 2008-2009, the banks were informed about the high level of risks of some real estate loans, but they choose deliberately to not divulge risk information and securitize their loans at financial institutions through innovative financial derivatives.

The main channels of transmission of the international financial crisis are through a decline in financial markets and trade volumes due to the high volatility of interest rate spreads, share prices, nominal exchange rates, house prices and deposit-loan ratio in banks. According to Borio (2006), the monetary policy suffers from the "paradox of credibility", which means that the policy of decreasing the interest rates to increase the liquidity can lead to a high volatility of asset prices with some negative macroeconomic impacts.

We postulate that the money is not neutral in the short and long run, so the international financial crisis shrinks the value of international liquidity, which affects net-exports and GDP. According to the herding behavior hypothesis (Aoki and Yoshikawa 2007, Chamley 2002), the financial and economic connection between economies facilitates the contagion through channels of foreign trade, exchange rate, stock exchange and bonds.

Since the financial crises of Latin-America and East Asia during the 1990s, the causes leading to the international financial crises come from the changes in terms of trade, world interest rates, exchange rates, banks credits and asset prices. Canova (2005) indicates that the financial channel plays a crucial role in the transmission of US shocks across countries. During the last international financial crisis, the large loss of the international reserves value is explained by the huge decrease in the prices of real estate assets in addition to the exchange rate deterioration. The economy is affected by the volatilities in asset prices, interest rates and exchange rates. We expect that the resistance of the economy to shocks of liquidity and credits would be limited.

Facing the investor's debts, banks charge higher interest rates on loans by adding some risk allowance as an insurance premium. However, risky investors are the most likely to be willing to pay the high interest rates, given the expected high rates of returns on their projects. By contrast, low risk and moderate returns projects may turn to be infeasible, given the high financing cost. Accordingly, Banks will be forced to finance mainly risky projects, a practice known as adverse selection, which endanger the financial stability of the banking sector. Looking for highest possible profits, some investors violate the loan contract by utilizing funds received from banks in rather riskier projects than those agreed upon in the contract. Thus, moral hazards raise banks' risk, increase interest rate on loans, and enhance adverse selection by banks, which all lead to inefficient allocation of financial resources and adverse impacts on the economy performance.

Blanchard (2009) indicates that the collapse of real estate sector drives the investors to sell their high risk real estate assets. The foreign financial capital shifts from real estate investment to government bonds investment, which is considered as the safe haven of international saving. This shifting limits the negative effects of the international financial crisis on the US dollar. Such behaviours expose the financial institutions to financial trouble and credit squeeze, due to their financial inability for supporting real economy which has negative impacts on the performance of the economies over the word. The financial globalization requires vigilance against the foreign moral hazard to reduce the drop in foreign assets values.

The falling (growing) energy prices will lead to reduced (expanded) investment and economic activity in GCC as oil exporters. The increase of net-exports and the current account excess lead to raise the monetary base, and allow the increase of official reserves and international liquidity.

The international financial markets attract international liquidity by offering augmented interest rates (Belke and Setzer 2010). Obviously, the importance of international liquidity reduces the control of central banks, and then they could not prevent undesirable effects of international liquidity volatilities on domestic macroeconomic and sectoral levels. In contrast, they attempt to face the inflation pressures by increasing the discount rate to shrink domestic liquidity. Such trap-liquidity policies could excite the financial institutions to re-invest in abroad financial markets, this paradoxical outcome means that the policy of increasing interest rates to reduce domestic liquidity can raise the international liquidity of domestic savers and the volatility of asset prices with ambiguous macroeconomic impacts.

The economic and financial theory does not examine extensively the relation between finance and 
economic growth. According to Demirgüç-Kunt and Levine (2008), prevailing theory provides ambiguous predictions about impacts of financial development on long-run economic growth; the empirical evidence would be less ambiguous. Knowing that the financial arrangements modify the preferences facing economic agents, financial systems and their interconnections could influence saving efforts, investment decisions, and then long-run economic growth.

The international liquidity would be reduced following the decrease in the current account balance due to the decline in net-capital account and in netexports, which is caused by the decrease in oil exports. Moreover, the decline in international liquidity could be caused by the shocks in international financial markets impacting the net-exports and GDP. When the financial channels dry out for diverse reasons such lack of liquidity, some contractions in public and private investment appear and conduct to more variability in net-exports and economic growth. The structural shocks in the international liquidity generate process of reactions in the economic activities and thus in the net result of foreign trade (Stiglitz 2000).

We stipulate that an expansionary monetary policy, generating structural positive shocks, would lead up to reduce the interest rate, and then extends the opportunities of investment projects. Also, the structural shocks of international financial markets generate many reactions related to international liquidity flows, net-exports and GDP.

Following Nowak, Andritzky, Jobst and Tamirisa (2009), we expect that the international liquidity shocks could occur from domestic (good or bad) news when the fiscal policy decides to increase the investmentGDP ratio or when the domestic stock markets become less (more) volatile, requiring less (more) domestic liquidity. In addition, the international liquidity shocks could happen from external financial markets as during the last international financial crisis (named bad news) or during high increase in external asset prices (named good news).

There are few empirical papers analyzing the effects of the international financial crisis on Saudi Arabia economy and more generally on the GCC countries. The contribution of this paper consists to analyze these effects through international liquidity of Saudi Arabia, net-exports and GDP.

Based on the above, the variability of each macroeconomic time series of Saudi economy namely international liquidity, net-exports and GDP is related to three types of structural shocks. These latter are foreign financial markets shocks influencing the level of international liquidity, foreign trade shocks through international trade determining the net-exports i.e. global demand addressed to Saudi Arabia minus Saudi demand addressed to the global economy, and supply shocks representing a sudden change in GDP.

\section{DATA AND VARIABLES}

The data consists of annual observations covering the previous four decades from 1968 to 2012 i.e. 45 observations, because the quarterly data are available only from 2005. The data comes from Annual report of Saudi Arabia Monetary Agency (SAMA), Central Department of Statistics and Information (CDSI) and International Financial Statistics (IFS). ${ }^{3}$ The underlying variables used are total reserve assets i.e. International Liquidity (IL), Net-exports $(N X)$ and Gross Domestic Product $(G D P)$. Other variables are utilized to improve the interpretation of the modelling results such credits to private sector, government expenditures and money supply or domestic liquidity, reflecting fiscal and monetary policies, respectively. All data are taken in real terms (1999 prices) with the appropriate deflators.

Plots over time of each variable in logarithm are visualized in Figures $\mathbf{3}$, which exhibit some additive outliers for international liquidity and net-export series. Many of the outliers' observations are due to many factors and stylized facts (section 2.2). The 1973-1974 outliers are the results of first oil shock caused by the Organization of Arab Petroleum Exporting Countries (OAPEC) embargo. The outlier in 1986 is due to the recession in industrialized economies and the outlier in 1998 is due to several oil production cuts by OPEC after a decrease of the crude oil prices. The dramatic political events of Gulf war in 1990-1991 explain the outlier in 1992 for international liquidity series. The outlier in 2009 is owing to a great decline of the oil prices in international market of crude oil prices from US dollar 145 to US dollar 40 during the first quarter of 2009.

Following Juselius (2006), some additive outliers should be removed prior to estimation and testing. According to Nielson (2004), the remove of outliers is basically equivalent to include impulse dummies in the

${ }^{3}$ http://www.sama.gov.sa/sites/samaen/ReportsStatistics/Pages/Home.aspx http://www.cdsi.gov.sa/ and http://imfstatext.imf.org/WBOS-Query/Index.aspx? DataSetCode=PGI 


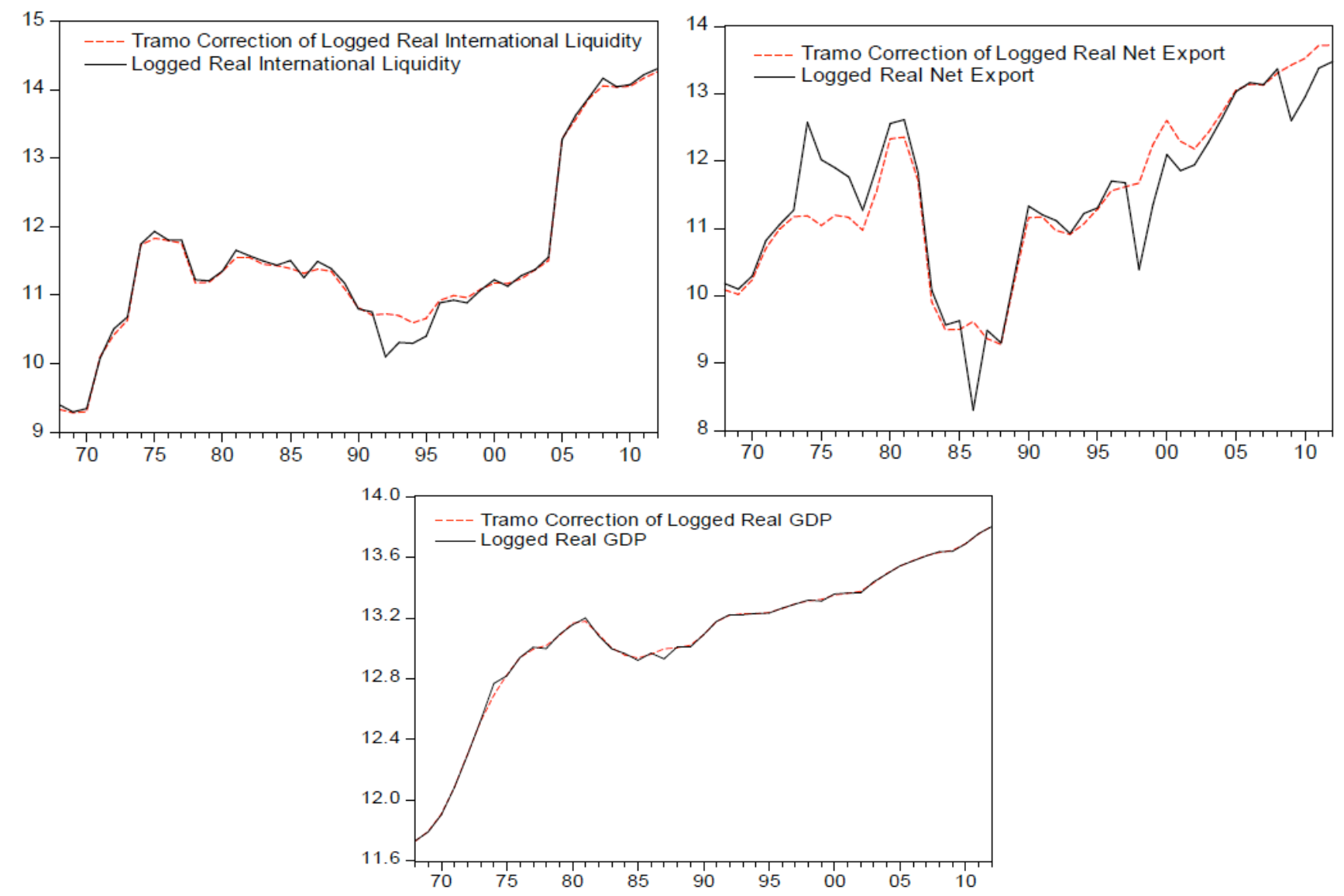

Figure 3: Observed (solid line) and corrected (dashed line) series of logged International Liquidity, Net-exports and GDP of Saudi Arabia from 1968 to 2012.

regression. To reduce the effects of outlier's observations on series features, we apply the TRAMO program using the linearised series in the estimation (Gomez and Maravall 1996). The results are displayed in Figure 3 with dashed lines.

The net-exports are defined by the difference between exports and imports of goods and services. Following the technical documents of IMF, the international liquidity contains five elements which are total reserves, official holdings of gold, foreign assets of monetary authorities, foreign liabilities of monetary authorities and foreign accounts of other financial institutions respectively. ${ }^{4}$

In normal situations, these components affect positively the economic growth. The variability of the reserves asset transactions (RAT) depends on the current account balance (CAB) and the net capital account (NKA) in the balance of payments. The relation between these components is $(C A B+N K A)+R A T=0$.

${ }^{4}$ http://www.imfstatistics.org/imf/IFSInter.htm and IMF.Stat
When $(C A B+N K A)>0$, an increase in net claims, which occurs in the form of official or private claims, on non-residents or in the acquisition of reserve assets on the part of the monetary authorities. Alternatively, when the sign is negative i.e. $(C A B+N K A)<0$, the net acquisition of resources from the rest of the world should be paid for by either liquidating foreign assets or increasing liabilities to non-residents (IMF 2009).

\section{SVAR MODEL SPECIFICATION}

The empirical models would explain the impacts of international financial crises on the Saudi economy performance. The negative difference between the economic growth and the growth of $M 3$, particularly since 1996 (Figure 1), makes that the hypothesis of "saving glut" effect is highly possible. This effect elucidates partially the level of Saudi international liquidity in international financial markets. The financial instability affects not only the financial system through sudden change in different financial prices or costs, but generates many significant disruptions on the financial market and the real economy (Allen and Wood 2006, Goodhart 2006). 
To apprehend the international dimension of the monetary policy, we use the total reserve assets of Saudi Arabia, which is related following a dynamic process to the net export flows and the economic growth. Accordingly, the model is a multivariate system of the economy, consisting of the international liquidity, net export and economic growth. The net export is included to capture economic policy effects on the economic growth rate (Wang 2010). By assuming that the conditional expectations follow a linear projection based on lags of the endogenous variables in the VAR model written as:

$X_{t}=c s t+\sum_{i=1}^{p} A_{i} X_{t-1}+\varepsilon_{t} \Leftrightarrow C(L) X_{t}=\varepsilon_{t}$

where $\quad X_{t}^{\prime}=\left(\operatorname{dln} I L_{t}, \operatorname{dln} N X_{t}, \operatorname{dln} G D P_{t}\right), C(L) \quad$ is the polynomial matrix of lag length, and $\varepsilon_{t}$ represents the reduced error term, with $E\left(\varepsilon_{t} \varepsilon_{t}^{\prime}\right)=\Omega_{\varepsilon} \quad$ and $E\left(\varepsilon_{t} \varepsilon_{t-1}^{\prime}\right)=0$. The VAR system can be rearranged as SVAR model by imposing restrictions on the matrices $A$ and $B$ of the following form (Breitung et al. 2004):

$$
A X_{t}=c s t_{0}+\sum_{i=1}^{p} A_{i}^{*} X_{t-1}+B u_{t}
$$

where $A_{i}^{*}$ is the matrix of structural coefficients, and $u_{t}$ is the structural error or shock, which is a white noise process with zero mean and time-invariant variancecovariance matrix $\Sigma_{u}$.

When the matrix $A$ is invertible, it allows to model contemporaneous relations among the variables of $X_{t}$.

By pre-multiplying with $A^{-1}, \boldsymbol{A}_{i}=A^{-1} \boldsymbol{A}_{i}^{*}$ for $i=1,2, \ldots, p$, we obtain the system (1) from (2) and the relation between reduced and structural errors is $\varepsilon_{t}=A^{-1} B u_{t}$ and its variance-covariance matrix is $\Omega_{\varepsilon}=A^{-1} B B^{\prime} A^{-1^{\prime}}$ by supposing that the shocks $u_{t}$ are orthogonal: $\Sigma_{u}=I$. This so-called AB-Model cannot be estimated without combining the restrictions on $A$ and $B$ that are consistent with a-priori theoretical expectations (Amisano and Giannini 1997). This way allows identifying economic and financial shocks. Given that the number of non-redundant elements of the variancecovariance matrix $\Omega_{\varepsilon}$ is $\mathrm{K}(\mathrm{K}+1) / 2$, where $\mathrm{K}$ is the number of endogenous variables in the VAR. Accordingly, we can identify just $\mathrm{K}(\mathrm{K}+1) / 2$ parameters of the structural VAR. Since there is $2 K^{2}$ elements in the matrices $A$ and $B$, the number of required restrictions to identify the full $A B$-model is $2 K^{2}-K(K+1) / 2$ which is equal to $K^{2}+K(K-1) / 2$. If the matrix $A$ or $B$ is set to be the identity matrix, then $\mathrm{K}(\mathrm{K}-1) / 2$ restrictions remain to be imposed.
To illustrate the identification principle for our purpose and taking into account the above analytical discussion, twelve restrictions are required to be imposed on the matrices $A$ and $B$. The first restrictions are linked to the unexpected innovation of international liquidity, which is influenced by the international financial markets (FM) shocks. Also, we suppose that the domestic real supply (DS) and foreign trade (FT) shocks do not affect contemporaneously the innovation of the Saudi international liquidity. The second restrictions come from the hypotheses that the innovations of net-exports are related jointly to the unexpected innovations of international liquidity and economic growth, and from the foreign trade shocks. The third required restrictions are deduced by considering that the innovations of reserve assets affect, through the international financial crisis shocks, the innovation of the GDP, which is also self-influenced by the domestic real supply shock. The structural model, reflecting previous "plausible" economic and financial assumptions by linking innovations and shocks, is:

$\left\{\begin{array}{l}\varepsilon_{t}^{I L}=b_{11} u_{t}^{F M} \\ \varepsilon_{t}^{N X}=a_{21} \varepsilon_{t}^{I L}+a_{23} \varepsilon_{t}^{G D P}+b_{22} u_{t}^{F T} \\ \varepsilon_{t}^{G D P}=a_{31} \varepsilon_{t}^{I L}+b_{33} u_{t}^{D S}\end{array}\right.$

where the coefficient $a_{i j}$ represents the response of variable $i$ to an unexpected shock in variable $j$, the coefficient $b_{i j}$ represents the response of variable $i$ to a structural shock in variable $j$. The first equation supposes that the international liquidity innovation $\varepsilon_{t}^{I L}$ is determined by the international financial crisis shocks through the parameter $b_{11}$. The second equation results from a saving relationship of the Keynesian framework, assuming that the parameter $a_{23}$ has a positive sign, also the impact of reserve assets innovations is expected to be positive. Finally, the third equation postulates that the innovations of GDP are driven by exogenous domestic real supply shocks; and according to the financial crisis shocks, it is expected that the parameter of the international liquidity innovation has a positive sign. The three equations correspond to an $\mathrm{AB}$-model and can be written as:

$$
\left[\begin{array}{ccc}
1 & 0 & 0 \\
-a_{21} & 1 & -a_{23} \\
-a_{31} & 0 & 1
\end{array}\right] \varepsilon_{t}=\left[\begin{array}{ccc}
b_{11} & 0 & 0 \\
0 & b_{22} & 0 \\
0 & 0 & b_{33}
\end{array}\right] u_{t}
$$

This system is just-identified since there are 6 restrictions for $A$ ( 3 zeros and 3 ones) and 6 restrictions 
Table 1: Unit Root Tests Results

\begin{tabular}{|c|c|c|c|c|}
\hline \multirow{2}{*}{ Variable } & \multicolumn{2}{|c|}{ Level } & \multicolumn{2}{c|}{ First difference } \\
\cline { 2 - 5 } & ADF & PP & ADF & PP \\
\hline \hline LIL & -1.123 & -1.431 & $-3.633^{*}$ & $-5.214^{* *}$ \\
\hline LNX & -1.727 & -1.806 & $-3.973^{* *}$ & $-4.006^{* *}$ \\
\hline LGDP & -1.948 & -3.026 & $-2.575^{*}$ & $-3.046^{*}$ \\
\hline
\end{tabular}

Note: " and indicate the reject of unit root at $1 \%$ and $5 \%$, respectively.

for $B$. Then, the parameters of the AB-model could be estimated by minimizing the negative of the concentrated log-likelihood:

$$
\begin{aligned}
& \ln L_{c}(A, B)=-\frac{K T}{2} \ln (2 \pi)+\frac{T}{2} \ln |A|^{2}-\frac{T}{2} \ln |B|^{2} \\
& -\frac{T}{2} \operatorname{tr}\left(A^{\prime} B^{\prime-1} B^{-1} A \tilde{\Omega}_{\varepsilon}\right)
\end{aligned}
$$

where $\tilde{\Omega}_{\varepsilon}=T^{-1} \sum_{t=1}^{T} \hat{\varepsilon}_{t} \hat{\varepsilon}_{t}^{\prime}$ is the estimated variancecovariance matrix of the VAR residuals with $\hat{\varepsilon} t=X t-\widehat{c s t}-\hat{A} Z_{t-1}$ and where $A=\left(A_{1}, A_{2}, \ldots, A_{i}, \ldots A_{p}\right)$ is the matrix $K \times K p$ and $Z_{t-1}^{\prime}=\left(X_{t-1}^{\prime}, X_{t-2}^{\prime}, \ldots X_{t-p}^{\prime}\right)$.

\section{EMPIRICAL RESULTS}

\subsection{Data Time Series Proprieties}

To properly specify the SVAR model, unit roots and cointegration tests are carried out. The unit roots are implemented using augmented Dickey-Fuller (ADF) and Phillips-Perron (PP) tests. There are at least four shifts in data during the period 1974 to 2009, which may affect the analysis. Firstly, the increase in oil price during 1973 after Yom Kippur war and Arab oil embargo leads to a significant raise in the international liquidity of Saudi Arabia. Secondly, the invasion of Kuwait known as Iraq-Kuwait war in 1991, which was related to the crude oil production quota of OPEC members, conducted to shrink the reserve assets transactions. Also from the period 1981 to 1986 has began a continuous decrease of net-exports, due to the recession in industrialized economies, driving to successive waves of diminution in OPEC oil production. This reduction was accompanied by a successive decrease in crude oil exports of Saudi Arabia and a successive decrease in nominal and real oil prices due partially to the role of strategic stocks (Energy Information Administration, US, http://www.eia.doe.gov/). Thirdly, the new waves of oil prices increasing after Venezuelan strikes, Nigeria unrest and the Iraq war started in 2003; in addition to the financial crisis since 2007-2008.
In the presence of such shifts, the PP test is more appropriate to check the ADF test. ${ }^{5}$ The test results are stated together in Table 1. The ADF and PP tests of unit root point out that the null hypothesis is accepted for all level variables, while the alternative hypothesis is accepted for all first difference variables.

The next purpose is to analyze whether the variables are long run cointegrated or not. For this, we apply the maximum likelihood procedure of Johansen and Juselius (1990). If the variables are cointegrated, the SVAR in first difference should be estimated in levels. The cointegration results are very sensitive to the lag length, for that reason we use the information criteria (AIC, SIC, HQ) obtained from a level VAR process. The criteria suggest two optimal lags 1 from SIC and $H Q$, and 2 from AIC. The lag exclusion test confirms individually and jointly the lag length 1 via Wald statistics, but only jointly the lag length 2 . As expected from previous studies, the SIC typically selects much shorter lags than AIC. Table 2 shows the results of cointegration test based on Johansen technique, indicating that there is no evidence of cointegration between the underlying variables i.e. international liquidity, net-exports and GDP. ${ }^{6}$ This result is validated from both the trace statistics and maximum eigenvalue, and with deterministic trend or without in the cointegrating equation (CE).

The absence of cointegration is a puzzling, but can be explained by the differences in intrinsic logic growth of each time series. Also, the limited sample size, frequency of observations and possible non-linearity of the relation could often explain the absence of cointegration (Engle and Granger 1991). Our purpose is focalised to know whether a cointegrating VAR would be a better alternative to the structural VAR in estimating the dynamic processes of the variables or

\footnotetext{
${ }^{5}$ The run of PP-test does not require dummies in the VAR model. ${ }^{6}$ When we run the Johansen-Juselius procedure, we don't need to pre-test with $\mathrm{ADF}$, and if the variables are stationary the test will find as many cointegrating relations as variables.
} 
Table 2: Cointegration Tests Results

\begin{tabular}{|c|c|c|c|}
\hline \multirow{2}{*}{ Trace statistics } & Hypothesized no. of CE(s) & $\begin{array}{c}\text { Test } \\
\text { Statistic }\end{array}$ & Critical value \\
\hline \hline \multirow{2}{*}{ Maximum eigenvalue } & None & 26.948 & 41.195 \\
\cline { 2 - 4 } & At most 1 & 13.677 & 19.078 \\
\cline { 2 - 4 } & At most 2 & 4.869 & 13.271 \\
\hline
\end{tabular}

Note: There is no deterministic trend, but restricted constant in CE.

not. Nevertheless, a SVAR is a VAR including a special identification scheme for residuals, which can be applied for both the cointegrated and first difference VAR models.

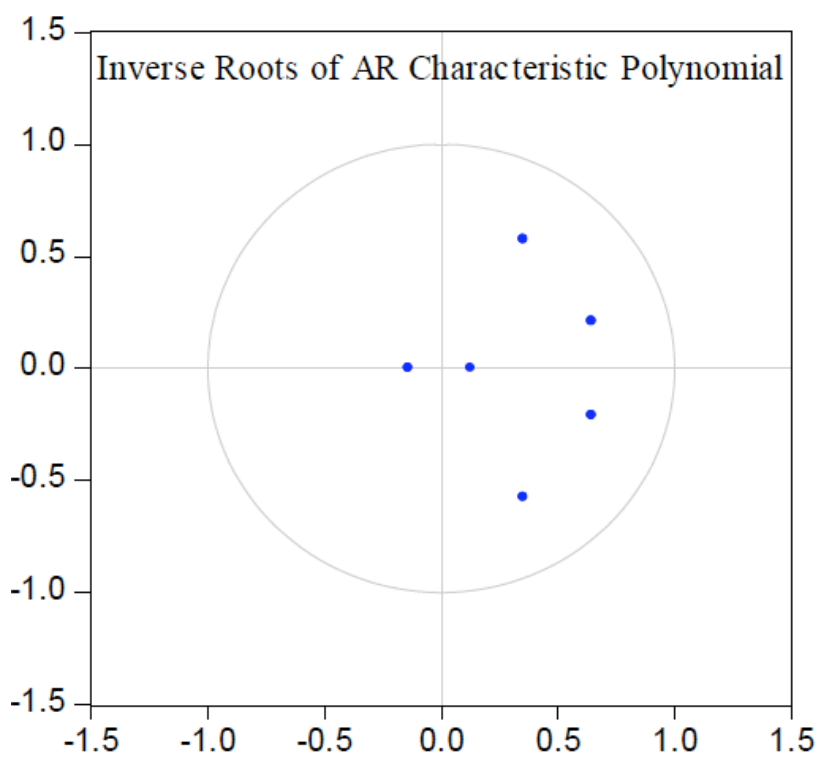

Figure 4: Stability test of VAR.

The absence of cointegration makes suitable to estimate the SVAR model in first difference, since there is no information in the long-run behaviour between variables that would be lost in the dynamic processes. The VAR is estimated, with two lags following the selection criteria tests, using stationary series obtained by differencing the logged variables leading to growth rate of international liquidity (dli), growth rate of netexports $(d \ln x)$ and real economic growth of GDP $(d l g d p)$. As revealed in Figure 4, all autoregressive characteristic polynomial roots lies within the unit circle, indicating that the VAR satisfies the stability condition.

To know if the data support the white noise errors assumption, the multivariate serial correlation of residuals is implemented. The Lagrange multiplier (LM) test accepts the null hypothesis of no autocorrelation (Table 3). Also, the VAR residual Portmanteau tests for autocorrelations indicate significant no serial correlation in the residuals. The Jarque-Bera test rejects jointly the null hypothesis of multivariate normality due to the excess in kurtosis and skewness from the individual equations of dlil and dlnx (Table 4).

The calculated residuals' correlation and variance matrices are shown in Tables 5 . Given the seemingly low values of residual covariances elements, the Likelihood Ratio (LR) test is implemented for the joint

Table 3: Lagrange Multiplier Tests Results

\begin{tabular}{|c|c|c|c|c|c|c|c|c|c|c|c|c|}
\hline Lags & $\mathbf{1}$ & $\mathbf{2}$ & $\mathbf{3}$ & $\mathbf{4}$ & $\mathbf{5}$ & $\mathbf{6}$ & $\mathbf{7}$ & $\mathbf{8}$ & $\mathbf{9}$ & $\mathbf{1 0}$ & $\mathbf{1 1}$ & $\mathbf{1 2}$ \\
\hline \hline LM & 12.9 & 20.6 & 3.9 & 8.7 & 5.1 & 9.7 & 10.3 & 2.1 & 18.2 & 10.0 & 10.1 & 14.6 \\
\hline Prob. & 0.16 & 0.01 & 0.92 & 0.47 & 0.82 & 0.37 & 0.32 & 0.98 & 0.03 & 0.35 & 0.34 & 0.10 \\
\hline
\end{tabular}

Table 4: VAR Residual Normality Tests Results

\begin{tabular}{|c|c|c|c|c|}
\hline & Joint & dlil & dlnx & dlgdp \\
\hline \hline Normality JB (Prob.) & $83.30(0.00)$ & $56.56(0.00)$ & $26.22(0.00)$ & $0.52(0.77)$ \\
\hline Skewness (Prob.) & $38.70(0.00)$ & $3.06(0.00)$ & $-1.03(0.01)$ & $-0.14(0.67)$ \\
\hline Kurtosis (Prob.) & $44.59(0.00)$ & $15.49(0.00)$ & $8.33(0.00)$ & $2.91(0.56)$ \\
\hline
\end{tabular}


significance of off-diagonal of the residual covariance matrix by testing the hypothesis that these off-diagonal elements of the unrestricted VAR are equals to zero using the Sims log likelihood ratio (Enders 2004). This test is crucial because if the nullity of residuals' covariances is true, we don't need to proceed with the SVAR model.

Table 5a: Residual Correlation Matrix

\begin{tabular}{|c|c|c|c|}
\hline & dlil & dInx & dlgdp \\
\hline \hline dlil & 1.0000 & 0.0511 & -0.0029 \\
\hline$d \ln x$ & 0.0511 & 1.0000 & 0.3331 \\
\hline$d l g d p$ & -0.0029 & 0.3331 & 1.0000 \\
\hline
\end{tabular}

Table 5b: Residual Covariance Matrix

\begin{tabular}{|c|c|c|c|}
\hline & dlil & dlnx & dlgdp \\
\hline \hline$d$ dlil & 0.1278 & 0.0066 & $-2.85 \mathrm{E}-05$ \\
\hline$d \ln x$ & 0.0066 & 0.1299 & 0.0032 \\
\hline$d l g d p$ & $-2.85 \mathrm{E}-05$ & 0.0032 & 0.0007 \\
\hline
\end{tabular}

The null hypothesis $H_{0}: \sigma_{12}=\sigma_{13}=\sigma_{23}=0$ is tested against the alternative hypothesis $H_{1}: \sigma_{12} \neq \sigma_{13} \neq \sigma_{23} \neq 0$ using the LR statistic which is given by: $L R=2\left(L L_{U}-L L_{R}\right)$ where $L L_{U}$ and $L L_{R}$ are the maximize values of the log-likelihood function with unrestricted model and restricted model, respectively. The LR is distributed following $\chi_{k}^{2}$ where $k$ is the degree of freedom equal to the number of added regressors. The log-likelihood value of the restricted model i.e. under $H_{0}$ comes from the single estimates of the equations in the VAR model and is defined by:

$L L_{R}=L L_{d l i l}+L L_{d l n x}+L L_{d l g d p}$

We get the log-likelihood value of the unrestricted model i.e. under $H_{1}$ from the VAR estimates. Using the lag length 1 , we obtain $L R=2(60.224-53.867)=12.714$ and from lag length 2 , the result is $=2(35.788-26.517)$ $=18.542$; the critical value at $95 \%$ level of significance and with degree of freedom $k=3$ is 7.815 . $^{7}$ The calculated values are greater than the critical value, so we reject the null hypothesis and then the covariance are not jointly zero i.e. the shocks in different equations

${ }^{7}$ By considering jointly the two lags length, we obtain $L R=2(73.143-70.608)=$ 5.07 and the critical value at $5 \%$ level of risk with degree of freedom $k=6$ is 12.59. Then, the null hypothesis is accepted and implies that the covariances are jointly zero. We exclude this result, because it does not serve our objective to analyze the dynamics of underlying variables through the financial and economic shocks. are contemporaneously correlated. This statistical feature justifies implementing SVAR model, which take into account the contemporaneous effects between underlying variables.

\subsection{SVAR Estimation}

The estimated shocks for the SVAR model are derived from the estimated VAR residuals using the structural factorization. The estimated structure of shocks is given by the following system (5), where the $P$-values are shown in the parenthesis. The coefficients of the structural shocks $u_{t}$ are their respective standard deviations.

$$
\left\{\begin{aligned}
\varepsilon_{t}^{I L}= & 0.379 u_{t}^{F M} \\
& (0.00) \\
\varepsilon_{t}^{N X}= & 0.465 \varepsilon_{t}^{I L}+2.089 \varepsilon_{t}^{G D P}+0.567 u_{t}^{F T} \\
& (0.00) \quad(0.17) \\
\varepsilon_{t}^{G D P}= & 0.036 \varepsilon_{t}^{I L}+0.056 u_{t}^{D S} \\
& (0.10) \quad(0.00)
\end{aligned}\right.
$$

The simultaneous relationship between the variables in the system (5) exhibits correct signs of all the coefficients as expected from economic theory. The particular interest is of the coefficient of the international liquidity innovation, which is significant at conventional level. It indicates that $I L$ appreciation in the international financial markets is related with an instantaneous tiny increase in economic growth and has a large impact on net-exports.

The effects of the structural shocks $u_{t}$ can be explored through an impulse response analysis. For this purpose, the estimated contemporaneous impact matrix and the second impact matrix could be obtained from the maximum likelihood estimates of the structural parameters:

$$
\tilde{A}^{-1} \tilde{B}=\Psi_{0}=\left[\begin{array}{ccc}
0.379 & 0.000 & 0.000 \\
0.205 & 0.567 & 0.116 \\
0.014 & 0.000 & 0.056
\end{array}\right] \text {, and } \Psi_{1}=\left[\begin{array}{ccc}
0.063 & -0.018 & 0.078 \\
-0.108 & -0.031 & 0.194 \\
0.003 & 0.010 & 0.036
\end{array}\right]
$$

To evaluate the pass-through, from international liquidity to net-exports and GDP, we use impulse response functions (IRF, Figure 5) and variance decomposition (VD) from our stylized SVAR model. The IRF is utilized to measure the effects of one time shock.

According to our estimated SVAR model, an international financial markets shock $u_{t}^{F M}$ increases international liquidity immediately, increases net- 

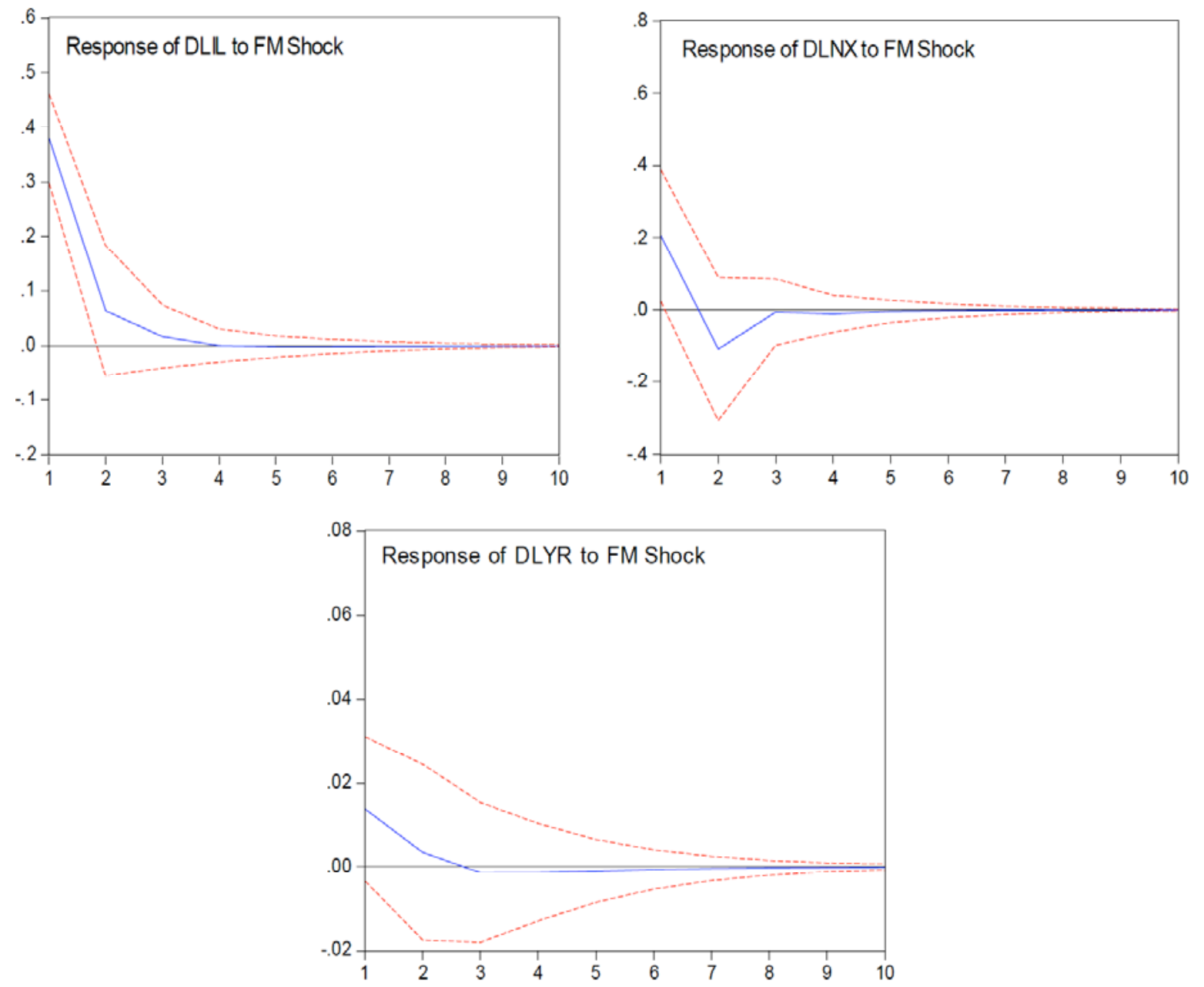

Figure 5: Impulse responses functions to financial markets shocks.

Note: Responses (solid line) of growth of international liquidity (IL), net-exports (NX) and GDP to structural one financial markets (FM) shocks with 95\% confidence intervals (dashed line).

exports for about the first one year but decreases it with a minimum response after two years, and enhances the GDP during the two first years and gradually drives down economic growth. Obviously, a positive shock -as sudden jumps up in the value of some assets- in the international financial markets could increase the belief in the confidence of investors, which generates immediately more international liquidity. The idea behind such immediate reactions could be related to sudden changes in stock markets returns and prices of assets. The savers are more confident for their foreign assets and do not divert their resources for alternatives uses, but are excited to expand more available international liquidity in the international financial markets for high-return risks in financial and real assets. This expansion depends on the stock of foreign reserves and on the domestic monetary conditions in addition to the domestic financial environment.

The positive shock generates some opportunities for the owners of the IL which are most encouraged to extend their specific financial products. The supply of IL will be increased in the financial markets, attracted by high-returns. The second year after the first international financial markets shock shows a positive self-impact, but largely reduced in magnitude. This finding can be explained by the fact that the opportunities in international financial markets pass away over time, caused by the discrepancies between demand and supply of capital.

From the second graph of Figure 5, the first positive shock of international financial markets leads to increase the growth of net-exports in Saudi Arabia economy. The explanation of this finding comes mainly from the economic growth of industrialized economies leading to import more crude oil which expands the international liquidity. Similarly, following the selfdynamic of the international liquidity, the net-exports responses are affected negatively in the second year of 
the time horizon. These reactions are consequence of the lack of best opportunities in the international financial markets, leading to a relative decline in the investment efforts. Such decline guides to reduce the trade between economies and in fine conducts to decrease the NX following a certain dynamic process.

After the first positive shock, the stability in the international financial markets would happen at least after three years where the probability of sudden shocks will be reduced progressively. The liquidity preference depends on the magnitude of the international financial markets shocks and tends to be less accentuated when the economic system has the ability to absorb over time the discrepancies and imbalances occurred in the international financial markets.

According to the first column of our estimated contemporaneous impact matrix and the second impact matrix, the dynamic interaction after the first shock of the IFM conducts to a tiny economic growth +0.003 in the second year after enhancing it in the first year by +0.014 . The explanation behind these dynamic implications is that the augmented IL in the IFM, during the two first years, could increase the NX in the economies characterized by excess saving and consequently leads to enhance the economic growth. During the second year, the decrease in IL has a negative impact on the NX, which reduce relatively the economic growth.

Considering a negative international financial markets shock, i.e. financial crisis, it conducts to reduce the domestic economic growth during roughly three years. Moreover, an international financial crisis shock leads to an immediate drop in the net-exports and to a gradual increase for about second year. This reaction is to avoid the shortage of reserves in the time horizon. It could be explained by the "liquidity preference effect" as in Keynesian approach or by the "income effect" as in Friedman theory of money.

The Table 6 shows the accumulated response of GDP to a structural one standard deviation shock to each of the variables. It reveals that the effect of international liquidity shock on GDP is enough gradual, taking about many years to arrive at its full level. The immediate effect to a positive financial market shock (which is 0.38 increase i.e. raises in the returns of financial assets) is about $1.38 \%$ increase in the economic growth. This implies a short-run elasticity of 0.036 . The full effect of this shock is about $1.17 \%$ increase in the economic growth, which leads to a dynamic pass-through elasticity of 0.031 .

Regarding the accumulated response of economic growth, the results indicate that a negative financial markets shock pass-through has a limited negative impact on GDP growth of Saudi economy, approximately less than $5 \%$. This finding is largely consistent with that of other studies such DemirgucKunt and Levine (2008). The negative international financial markets shock could induce the monetary authorities (SAMA) to change their policies by reducing the size of reserves assets invested abroad. Such reactions lead to economic growth through the increase of private and government investments. Since the short and long run effects of financial markets shock on economic growth do not exhibit negative signs, then there is no crowding-out between domestic investment and investment in foreign assets ${ }^{8}$. But, it remains that the long-run shifting from saving glut effect to absorption effect would increase the rate of investment to real GDP, which is in average during the two last decades less than 20\% (Kenc and Dibooglu 2010).

Table 6: Short-Run and Long-Run Pass-Through Elasticities of Saudi GDP

\begin{tabular}{|c|c|c|c|}
\hline SVAR & dlil & dlnx & dlgdp \\
\hline \hline$h=1$ & 0.0138 & 0.0000 & 0.0557 \\
\hline$h=\infty$ & 0.0117 & 0.0279 & 0.1534 \\
\hline$\sigma_{u}$ & 0.3796 & 0.5676 & 0.0557 \\
\hline Impact elasticities & 0.0361 & 0.0000 & 1.0000 \\
\hline Dynamic elasticities & 0.0309 & 0.0492 & 2.7530 \\
\hline
\end{tabular}

The variance decomposition separates the forecast error variance of economic growth into components that can be attributed to each of the three shocks to the system. Then, to calculate the relative importance of the identified international financial markets shocks, we list for different horizons $h$ the forecast error variance decomposition of the economic growth in Table 7. Obviously, according to our estimates, domestic supply shocks are the dominant source for Saudi economic growth. Even in the long-run about $93 \%$ of the variation in economic growth variable can be attributed to

\footnotetext{
${ }^{8}$ The dynamic of crowding effect between the international liquidity and the domestic liquidity could be analyzed, taking into account the volatility of international crude oil prices, to determine if the economic and monetary policies lead to raise the economic efficiency in government and private sectors.
} 
Table 7: Forecast Error Variance (S.E.) Decomposition of Saudi GDP

\begin{tabular}{|c|c|c|c|c|}
\hline $\mathbf{h}$ & $\mathbf{S . E .}$ & $\mathbf{u}^{\mathrm{FM}}$ & $\mathbf{u}^{\mathrm{FT}}$ & $\mathbf{u}^{\text {DS }}$ \\
\hline \hline 1 & 0.05742 & 5.777 & 0.000 & 94.223 \\
\hline 2 & 0.06866 & 4.291 & 2.337 & 93.371 \\
\hline 4 & 0.07449 & 3.713 & 3.011 & 93.276 \\
\hline 8 & 0.07543 & 3.651 & 3.132 & 93.217 \\
\hline$\infty$ & 0.07545 & 3.649 & 3.135 & 93.216 \\
\hline
\end{tabular}

domestic supply shocks. Although, foreign trade shocks are not important at short horizons, they explain $3.1 \%$ of the variance in economic growth as $h$ increases.

In contrast, financial markets shocks contribution decreases as $h$ increases and explains a fraction of $6 \%$ to $4 \%$ of GDP growth variance, respectively. This highlights the persistence of such shocks at time horizon. Clearly, since the GDP growth variance is explained at high rate by its own shocks, there are other factors that have significant role in Saudi's economic growth process. We can consider that international crude oil prices tend to play increasingly important role in Saudi's economic growth of oil-GDP and non-oil-GDP sectors.

\subsection{Temporal Asymmetric Causality}

Obviously, the dynamic impacts depend on the sign of the shocks which generate different reactions justifying the presence of the asymmetry. Nonlinearities are difficult to model, because the available observations are not large. Since our analysis is limited by the lack of statistical information on quarterly frequency, we can consider the temporal asymmetry in the VAR framework instead of threshold VAR. The concept of temporal asymmetry differs from the contemporaneous asymmetry, it occurs when the changes of variable $x$ depend on the changes of lagged variable $y$.

Our goal is to find out if the impacts of a positive international financial markets shock on net-exports and GDP is not significantly different from the impacts of a negative shock. To capture the reactions of real economic growth and net-exports change to an increase and decrease of international liquidity change, we decompose the series dlil using a threshold parameter of zero. According to Granger and Lee (1989), the VAR mechanic will use the following variables:
$X_{t}^{\prime}=\left\{\begin{array}{lr}\left(\Delta \ln I L_{t}^{+}, \Delta \ln N X_{t}, \Delta \ln G D P_{t}\right) & \text { if } \Delta \ln I L_{t}>0 \\ \left(0, \Delta \ln N X_{t}, \Delta \ln G D P_{t}\right) & \text { otherwise }\end{array}\right.$

$X_{t}^{\prime}=\left\{\begin{array}{lr}\left(\Delta \ln I L_{t}^{-}, \Delta \ln N X_{t}, \Delta \ln G D P_{t}\right) & \text { if } \Delta \ln I L_{t}>0 \\ \left(0, \Delta \ln N X_{t}, \Delta \ln G D P_{t}\right) & \text { otherwise }\end{array}\right.$

The inspection of the changes in real international liquidity reveals that during the international financial crisis only the year 2009 exhibits a negative growth since 2002 (Figure 6). The Wilcoxon test on the variable dlil, based on the idea that the sum of the ranks for the sample above and below the median should be similar (e.g. as null hypothesis), shows that this null hypothesis is rejected at $5 \%$ significance level. ${ }^{9}$ This test justifies that the positive values of dlil do not have the same median compared to its negative value; this result leads to that the presumption of asymmetric behaviour between positive international liquidity changes compared to negative ones.

We focus on the effects of the structural shocks $u_{t}$ in short and long run by exploring the impulse responses from the SVARs related to the VAR using variables defined in (6) and (7), respectively. The Table 8 shows, in the asymmetric cases, the accumulated response of GDP to a structural one standard deviation shock to each one of the variables. It indicates that the effect of international liquidity shocks on GDP is enough gradual, taking number of years to arrive at its full level. The immediate effect to a positive financial market shock (which is 0.31 increase i.e. raises in the returns of financial assets) is about $1.25 \%$ increase in the real economic growth. This displays a short-run elasticity of 0.04 . The full effect of this shock is about $1.01 \%$ increase in the real economic growth, which leads to a dynamic pass-through elasticity of 0.032 .

${ }^{9}$ Wilcoxon-test is similar to the basic principle of the dependent data t-test. It tests the difference between two observations that has a mean signed rank of 0 . It is robust against outliers and heavy tail distributions http://statisticssolutions.com/academic-solutions/resources. 

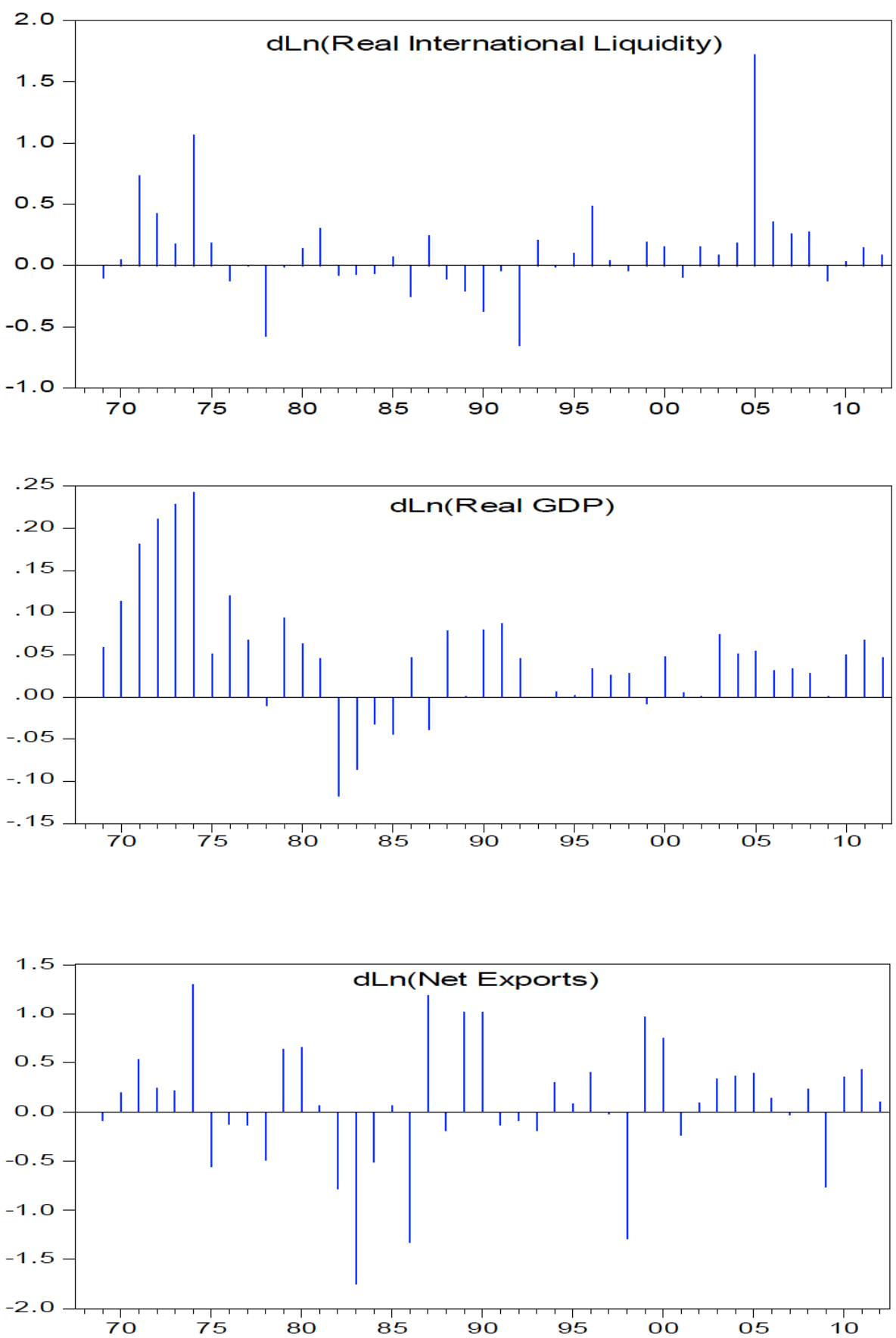

Figure 6: Observed series of first difference of logged International Liquidity, Net-exports and GDP of Saudi Arabia from 1969 to 2012.

Table 8: Asymmetric Short-Run and Long-Run Pass-Through Elasticities of Saudi GDP

\begin{tabular}{|c|c|c|c|}
\hline SVAR $^{+}$ & dlil & dlnx & dlgdp \\
\hline \hline$h=1$ & 0.0125 & 0.0000 & 0.0559 \\
\hline$h=\infty$ & 0.0101 & 0.0266 & 0.1530 \\
\hline$\sigma_{u}$ & 0.3141 & 0.5786 & 0.0559 \\
\hline Impact & 0.0399 & 0.0000 & 1.0000 \\
\hline Dynamic & 0.0321 & 0.0460 & 2.7339 \\
\hline
\end{tabular}


(Table 8). Continued.

\begin{tabular}{|c|c|c|c|}
\hline SVAR & dlil & dlnx & dlgdp \\
\hline \hline$h=1$ & 0.0000 & 0.0000 & 0.0579 \\
\hline$h=\infty$ & -0.0104 & 0.0207 & 0.1591 \\
\hline$\sigma_{u}$ & 0.1488 & 0.5968 & 0.0579 \\
\hline Impact & 0.0000 & 0.0000 & 1.0000 \\
\hline Dynamic & -0.0699 & 0.0347 & 2.7443 \\
\hline
\end{tabular}

The external financial market shocks are source of macroeconomic instability, the negative shock leads to reduce the economic growth in the long-run by $1.04 \%$, whereas the positive shock droves to increase in longrun the GDP growth by $1.01 \%$. This outcome is basically consistent with the results of Mackowiak paper (2007), indicating that the external shocks are an important origin of macroeconomic fluctuations in emerging economies.

\section{CONCLUSIONS AND SOME POLICY IMPLICATIONS}

The impacts of the international financial crisis on real economy of the Kingdom of Saudi Arabia require a deep analysis of the mechanisms linked to financial shocks by using structural vector autoregressive model (SVAR) in linear and non-linear framework. The absence of cointegration between the underlying variables international liquidity, net export and GDP reveals that there is an intrinsic logic growth of each time series. The negative international financial markets shock conducts to reduce the domestic economic growth during almost three years. Also, it leads to an immediate drop in the net-exports, but to a gradual increase from the second year. These results can be explained by the liquidity preference effect, so the monetary authorities (SAMA) have to change their policies by reducing the size of reserves assets invested abroad. Such reactions lead possibly to economic growth through the increase of private and government investments. Since the short and long run effects of financial markets shock on economic growth do not exhibit negative signs, then there is no crowding-out between domestic investment and investment in foreign assets. But, it remains that the long-run shifting from saving glut effect to absorption effect would increase the potential ratio of domestic investment to real GDP. Since the GDP growth variance is explained at high rate by its own shocks, there are other factors that have significant role in Saudi's economic growth process; mainly the international crude oil prices tend to play increasingly their role in Saudi's economic growth of oil-GDP and non-oil-GDP.

Considering the asymmetric SVAR, the accumulated response of GDP to a structural one standard deviation shock indicates that the effect of international liquidity shocks on GDP is enough gradual, taking number of years to arrive at its full level. The full effect of positive shock is about $1.01 \%$ increase in the real economic growth leading to a positive dynamic pass-through elasticity of 0.032 , whereas the negative shock droves to reduce the economic growth by $1.04 \%$ driving to a negative dynamic pass-through elasticity of 0.070 .

Even if the impacts of the international financial crisis are limited, the economic and financial recovery of Saudi economy is not automatic, it depends on the monetary and financial policies choices. To boost domestic GDP, the Saudi economy has to improve real competitiveness, increase non-oil output and decrease imports without causing deep recession. Also, the economic cooperation and coordination between GCC countries, by establishing free trade agreement, would help to realize such goals. The institutional factors are important leading to have open, fair and vibrant markets to support sustainable growth and to attract multinational corporations. These firms bring in new technologies, risk-sharing capital, foreign exchange and connections to international markets. The current crisis will increase the motivation to diversify the commercial and financial partners, reducing then progressively the reliance on the US dollar and US economy. To be operated, such progressive disconnection on the US dollar requires that the GCC economies establish the expected "GCC-currency" in the near future and diversify the sources of their revenues and improves their petro-chemical sectors.

The pathways of future research with this topic are to separate the international liquidity on private and public components, and to consider real investments versus speculative investments in international financial markets. Also, it is interesting to explore what would 
happen without the huge money-help of central banks to banking and financial systems.

\section{ACKNOWLEDGEMENTS}

This research began while I was a Professor in the department of economics at the King Faisal University (KFU). We would like to thank the Deanship of Scientific Research in KFU for granting and supporting this research. For comments and suggestions, we are grateful to Professor Stefano Fachin and to anonymous referees.

\section{REFERENCES}

Allen W. and G. Wood. 2006. "Defining and achieving financial stability." Journal of Financial Stability 2(2):152-172. http://dx.doi.org/10.1016/j.jfs.2005.10.001

Amisano G. and C. Giannini. 1997. "Topics in Structural VAR Econometrics." ${ }^{d}$ Edition, Springer-Verlag, Berlin. http://dx.doi.org/10.1007/978-3-642-60623-6

Aoki M. and H. Yoshikawa. 2007. "Reconstructing Macroeconomics: A Perspective from Statistical Physics and Combinatorial Stochastic Processes." Cambridge University Press.

Belke A., W. Orth and R. Setzer. 2010. "Liquidity and the dynamic pattern of asset price adjustment: A global view." Journal of Banking \& Finance 34(8):1933-1945. http://dx.doi.org/10.1016/i.jbankfin.2009.12.012

Blanchard O. 2009. "The Perfect Storm." Finance and Development, June:37-39.

Bordo MD., CM. Meissner and D. Stuckler. 2010. "Foreign currency debt, financial crises and economic growth: A long-run view." Journal of International Money and Finance 29(4):642-665. http://dx.doi.org/10.1016/j.jimonfin.2010.01.002

Borio C. 2006. "Monetary and financial stability: here to stay?" Journal of Banking \& Finance 30(12):3407-3414. http://dx.doi.org/10.1016/j.jbankfin.2006.06.004

Bourland B. 2008. "Saudi Arabia and the global financial crisis." Monthly Bulletin of Jadwa Investment December:1-15. http://www.jadwa.com/en/researchsection/research/

Bracke T. and M. Fidora. 2008. "Global Liquidity Glut or Global Savings Glut?" Working Paper Series, European Central Bank 911. http://www.ecb.europa.eu

Breitung J., R. Brüggemann and H. Lütkepohl. 2004. "Structural Vector Autoregressive modeling." Chapter 4 in $\mathrm{H}$. Lutkepohl and M. Kratzig (Eds.), Applied Time Series Econometrics. Cambridge University Press. http://dx.doi.org/10.1017/CBO9780511606885.005

Canova F. 2005. "The transmission of US shocks to Latin America." Journal of Applied Econometrics 20:229-251. http://dx.doi.org/10.1002/jae.837

Calvo G. 1998. "Capital Flows and Capital-Market Crises: The Simple Economics of Sudden Stops." Journal of Applied Economics I(1):35-54.

Chamley C.P. 2002. "Rational Herds: Economic Models of Social Learning." Cambridge University Press: Cambridge.

Clarida R.H. 2005. "Japan, China, and the U.S. Current Account Deficit." CATO Journal 25:111-114.

Colander D., H. Follmer, A. Haas, M. Goldberg, K. Juselius, A. Kirman, Th. Lux and B. Sloth. 2009. "The financial crisis and the systemic failure of academic economics." Kiel Working Papers No. 1489. http://www.ifw-members.ifwkiel.de/publications/
Dell' Ariccia G., E. Detragiache and R. Rajan. 2008. "The Real Effects of Banking Crises." Journal of Financial Intermediation 17:89-112. http://dx.doi.org/10.1016/.j.fi.2007.06.001

Demirguc-Kunt A., and R. Levine. 2008. "Finance, financial sector policies and long-run growth." Commission on growth and development, Working Paper No. 11, World Bank. http://wwwwds.worldbank.org/servlet/WDSContentServer/W DSP/IB/2008/01/07/000158349_20080107115116/Rendered/ PDF/wps4469.pdf

Edwards S. 2006. "Monetary unions, external shocks and economic performance: A Latin American perspective." International Economics and Economic Policy 3:225-247. http://dx.doi.org/10.1007/s10368-006-0056-2

Enders W. 2004. "Applied econometric time series." New York: John Wiley \& Sons.

Engle RF. and CWJ. Granger (Eds.). 1991. "Long Run Economic Relations: Readings in Cointegration." Oxford University Press, Oxford.

Galindo A., F. Schiantarelli and A. Weiss. 2007. "Does Financia Liberalization Improve the Allocation of Investment? Microevidence from Developing Countries." Journal of Development Economics 83(2):562-587. http://dx.doi.org/10.1016/j.jdevec0.2005.09.008

Goodhart C. 2006. "A Framework for Assessing Financial Stability?" Journal of Banking and Finance 30(12):3415-3422. http://dx.doi.org/10.1016/j.jbankfin.2006.06.003

Gomez V., and A. Maravall. 1996. "Programs TRAMO and SEATS, Instruction for User (Beta Version)." Bank of Spain. Working Papers 9628.

Granger CWJ. and TH. Lee. 1989. "Investigation of production sales and inventory relationship using multi-cointegration and non symmetric error correction models." Journal of Applied Econometrics 4:145-159. http://dx.doi.org/10.1002/jae.3950040508

IMF. 2008. "Spillovers to Emerging Equity Markets." Global Financial Stability Report, October:131-151.

IMF. 2009. "Balance of Payments and International Investment Position Manual." Sixth edition. Washington DC.

Johansen S. and K. Juselius. 1990. "Maximum Likelihood Estimation and Inference on Cointegration - with Applications to the Demand for Money." Oxford Bulletin of Economics and Statistics 52:169-210. http://dx.doi.org/10.1111/j.1468-0084.1990.mp52002003.x

Juselius K. 2006. "The cointegrated VAR model: Methodology and Applications." Oxford University Press: Oxford.

Kashyap A., Rajan R., and J. Stein. 2008. "The Global Roots of the Current Financial Crisis and its Implications for Regulation." Paper Presented at the Bank of Finland, Helsinki.

Kenc T. and S. Dibooglu. 2010. "The 2007-2009 Financial Crisis, Global Imbalances and Capital Flows: Implications for Reform." Economic Systems 34:3-21. http://dx.doi.org/10.1016/j.ecosys.2009.11.003

Mackowiak B. 2007. "External shocks, US monetary policy and macroeconomic fluctuations in emerging markets." Journal of Monetary Economics 54:2512-2520. http://dx.doi.org/10.1016/j.jmoneco.2007.06.021

Mehrara M. and KN. Oskoui. 2007. "The sources of macroeconomic fluctuations in oil exporting countries: A comparative study." Economic Modelling 24(3):365-379. http://dx.doi.org/10.1016/i.econmod.2006.08.005

Michaud FL. and C. Upper. 2008. "What Drives Interest Rates? Evidence from the Libor Panel." Bank for International Settlements Quarterly Review (March):47-58.

Morrison WM. and M. Labonte. 2008. "China's holdings of US securities: implications for the US economy." CRS Report for Congress. Order Code RL34314. Congressional Research Service. 
Nielson HB. 2004. "Cointegration analysis in the presence of outliers." Econometrics Journal 7:249-271. http://dx.doi.org/10.1111/j.1368-423X.2004.00130.x

Nowak S., JR. Andritzky, A. Jobst, and NT. Tamirisa. 2009. "Macroeconomic Fundamentals, Price Discovery and Volatility Dynamics in Emerging Markets." International Monetary Fund Working Paper No 09/147.

Portes R. 2009. "Global imbalances." In M Dewatripont, X Freixas, and $\mathrm{R}$ Portes (eds.), Macroeconomic stability and financial regulation: Key issues for the G20, Centre for Economic Policy Research.

Reinhart CM. and K. Rogoff. 2008. "This Time is Different: Eight Centuries of Financial Folly." Princeton: Princeton University Press.

http://dx.doi.org/10.3386/w13882
Roubini N. and B. Setser. 2005. "Will the Bretton Woods 2 Regime Unravel Soon? The Risk of a Hard Landing in 2005-2006." Federal Reserve Bank of San Francisco Proceedings, February.

Sester B. and R. Ziemba. 2007. "Understanding the new Financial Superpower: the Management of GCC Official Reserves Assets." Roubini Global Economics (RGE) Monitor.

Stiglitz J. 2000. "Capital Market Liberalization, Economic Growth and Instability." World Development 28(6):1075-1086. http://dx.doi.org/10.1016/S0305-750X(00)00006-1

Wang P. 2010. "The Economics of Foreign Exchange and Global Finance." ISBN: 978-3-642-11136-5, Springer.

Woertz E. 2008. "Impact of the US Financial Crisis on GCC Countries." Gulf Research Center GRC, October Report, Dubai.

Received on 07-06-2013

Accepted on 28-10-2013

Published on 13-11-2013

DOI: http://dx.doi.org/10.6000/1929-7092.2013.02.27

(C) 2013 Ghassan et al.; Licensee Lifescience Global.

This is an open access article licensed under the terms of the Creative Commons Attribution Non-Commercial License (http://creativecommons.org/licenses/by-nc/3.0/) which permits unrestricted, non-commercial use, distribution and reproduction in any medium, provided the work is properly cited. 